\title{
AKNA wt Allele
}

National Cancer Institute

\section{Source}

National Cancer Institute. AKNA wt Allele. NCI Thesaurus. Code C158843.

Human AKNA wild-type allele is located in the vicinity of $9 q 32$ and is approximately $64 \mathrm{~kb}$ in length. This allele, which encodes AT-hook-containing transcription factor protein, plays a role in the transcriptional activation of the CD40 and CD40LG genes. 